\title{
Pengaruh Bimbingan Praktik Tilawah terhadap Motivasi Menghafal Al-Quran
}

\author{
Ulfa Novianti Saeful* \\ Jurusan Bimbingan dan Konseling Islam, UIN Sunan Gunung Djati, Bandung \\ *Email: ulfanovianti313@gmail.com
}

\begin{abstract}
ABSTRAK
Penelitian ini bertujuan untuk mengungkapkan respon mahasiswa terhadap proses bimbingan praktik tilawah, motivasi menghafal Al-Quran, serta pengaruh bimbingan praktik tilawah terhadap motivasi menghafal Al-Quran mahasiswa angkatan 2014 Jurusan Bimbingan Konseling Islam UIN Sunan Gunung Djati Bandung. Metode penelitian ini adalah kuantitatif. Adapun populasi dalam penelitian ini yaitu sebanyak 185 orang dengan sampel 64 responden. Dari hasil penelitian diperoleh pengaruh bimbingan praktik tilawah terhadap motivasi menghafal Al-Quran mahasiswa angkatan 2014 Jurusan Bimbingan Konseling Islam Fakultas Dakwah dan Komunikasi UIN Sunan Gunung Djati Bandung yaitu sebesar 72,25\% dan sisanya sebesar 27,75\% dipengaruhi oleh variabel lain. Respon mahasiswa Jurusan Bimbingan Konseling Islam Angkatan 2014 terhadap proses pelaksanaan bimbingan praktik tilawah sangat tinggi hal ini disebabkan oleh tata cara atau metode yang dilakukan oleh pembimbing dalam melaksanakan bimbingan. Mahasiswa Jurusan Bimbingan Konseling Islam Angkatan 2014 memiliki perencanaan dalam aktivitas menghafal Al-Quran, memiliki pencapaian tujuan yang diinginkan, memiliki kesadaran untuk menghafal Al-Quran, menghargai dan menerima pembimbing yang mengajarkan hafalan Al-Quran, serta memiliki rasa ingin tahu yang tinggi dalam proses menghafal Al-Quran.
\end{abstract}

\section{Kata Kunci: Bimbingan Praktik Tilawah; Motivasi Menghafal Al-Quran}

\section{ABSTRACT}

This research as a purpose to reveal the response of students to the process of guidance tilawah practices, motivation to Al-Quran memorize, and the influence of guidance tilawah practices on the motivation to Al-Quran memorize students force 2014 Islamic Guidance and Counseling majors in UIN Sunan Gunung Djati Bandung. This research method used quantitave method. The population in this research is as 185 peoples with a sample of 64 respondents. 


\section{U. N. Saeful}

From the research results obtained the influence of guidance tilawah practices on the motivation to Al-Quran memorize students force 2014 Islamic Guidance and Counseling majors Faculty of Dakwah and Communication in UIN Sunan Gunung Djati Bandung that is equal to $72,25 \%$ and the rest of $27,75 \%$ influenced by other variables. The respons of students of Islamic Guidance and Counseling majors force 2014 on the implementation process of guidance tilawah practices is very high this is caused by the procedures or methods used by counsellor in carrying out guidance. Students of Islamic Guidance and Counseling majors force 2014 has a plan in Al-Quran memorizing activities, have the achievement of the desired goals, have awareness to Al-Quran memorize, appreciate and receive cousellor or mentor who teach rote Al-Quran, and have a bigh curiosity in the process memorizing Al-Quran.

Keywords: Guidance Tilawah Practices, Motivation to Al-Quran Memorize

\section{PENDAHULUAN}

Al-Quran merupakan kitab suci yang diturunkan Allah Swt kepada Nabi Muhammad Saw sebagai mukjizat terbesar di antara mukjizat-mukjizat yang lainnya. Al-Quran sebagai kitab terakhir dimaksudkan untuk menjadi petunjuk bagi seluruh umat manusia (hudan linnas) sampai akhir zaman. Di dalamnya terkandung nilai-nilai yang luhur mencakup seluruh aspek kehidupan manusia dalam berhubungan dengan Tuhan, maupun hubungan manusia dengan manusia, serta hubungan manusia dengan alam sekitarnya (Daulay, 2014: 31).

Al-Quran sebagai mu’jizat yang besar, maka di dalamnya terdapat pedoman dalam mencapai kehidupan yang hakiki. Oleh karena itu, kewajiban setiap muslim di seluruh penjuru dunia untuk mempelajari Al-Quran dengan cara membaca, menghafal, serta mengamalkannya. Menurut Sa'dulloh (dikutip dari Badriyah, 2014: 1) individu yang mempelajari Al-Quran diberikan banyak keistimewaan sekaligus tanggung jawab untuk menyebarkan apa yang dipelajarinya kepada orang lain melalui jalan dakwah. Adapun keutamaan membaca dan menghafal Al-Quran adalah individu yang mengamalkannya akan menjadi sebaik-baiknya manusia, dinaikkan derajatnya oleh Allah Swt, ditentramkan hatinya dan senantiasa dibentengi dari siksaan, serta dijauhkan dari penyakit menua yaitu kepikunan.

Mengingat pentingnya membaca dan menghafal Al-Quran, maka UIN Sunan Gunung Djati Bandung mewajibkan mahasiswa untuk menghafal AlQuran minimal 1 juz yaitu juz 30 sebagai salah satu persyaratan ujian munaqosah. Dengan begitu, Fakultas Dakwah dan Komunikasi mewajibkan kepada seluruh mahasiswanya untuk mengikuti kegiatan praktik tilawah pada semester 3 sebagai salah satu persyaratan dalam mengikuti kegiatan PPM/Job Training dan menempuh ujian komprehensif. Program praktik tilawah ini sesuai 
dengan keputusan Menteri Agama Republik Indonesia Nomor: 39 Tahun 2010 tentang Status Universitas Islam Negeri Sunan Gunung Djati Bandung. Keputusan Rektor UIN Sunan Gunung Djati Bandung Nomor: Un.05/I.1/PP.00.9/082A/2012 tentang Pedoman Akademik UIN Sunan Gunung Djati Bandung Tahun 2013. Keputusan Dekan Fakultas Dakwah dan Komunikasi UIN Sunan Gunung Djati Bandung Nomor: Un.05/III.4/PP.00.9/2192/2012 tentang Panduan Akademik Fakultas Dakwah dan Komunikasi UIN Sunan Gunung Djati Bandung Tahun 2013 (Panduan Penyelenggaraan Praktik Tilawah, 2015: 6).

Kegiatan bimbingan praktik tilawah meliputi kegiatan pembimbingan baca-tulis dan tahfidh Al-Quran dan hadits berikut simulasi dan penugasan pesan dakwah yang diturunkan dari Al-Quran dan hadits. Salah satu materi pokok dalam bimbingan praktik tilawah ini yaitu membaca, menulis, dan menghafalkan ayat-ayat Al-Quran. Bimbingan praktik tilawah ini membantu mahasiswa untuk melatih dan membiasakan diri untuk menghafal Al-Quran.

Berdasarkan data awal hasil penelitian yang dilakukan pada tanggal 17 November 2017 kepada enam orang mahasiswa angkatan 2014 Jurusan Bimbingan Konseling Islam Fakultas Dakwah dan Komunikasi UIN Sunan Gunung Djati Bandung. Terdapat tiga orang mahasiswa yang merespon baik terhadap adanya kegiatan bimbingan praktik tilawah yang dapat memberikan energi positif kepada setiap individu sehingga mereka termotivasi untuk menghafal Al-Quran. Sedangkan tiga orang mahasiswa lainnya kurang memberikan respon baik terhadap adanya kegiatan bimbingan praktik tilawah sehingga mereka tidak termotivasi untuk menghafal Al-Quran.

Adapun dari hasil penelitian tersebut, peneliti mendapatkan data bahwa faktor yang menyebabkan adanya motivasi untuk menghafal Al-Quran dari kegiatan bimbingan praktik tilawah tersebut yaitu faktor kesadaran serta keinginan yang timbul dalam diri masing-masing untuk menghafal Al-Quran, faktor latar belakang pendidikan, selain itu faktor tuntutan dari setiap dosen pembimbing untuk menghafal ayat-ayat Al-Quran tersebut dijadikan sebagai sebuah tantangan sehingga mereka semangat untuk menghafal Al-Quran, dan juga faktor lingkungan khususnya teman sekelompok yang saling memberikan motivasi satu sama lain.

Adapun faktor yang menyebabkan tidak adanya motivasi untuk menghafal Al-Quran yaitu belum adanya keinginan dalam diri mereka untuk memulai sedikit demi sedikit untuk menghafal Al-Quran hal ini disebabkan karena mereka telah melakukan judgement terlebih dahulu terhadap dirinya sendiri bahwa tidak mampu untuk menghafal Al-Quran sehingga menimbulkan rasa pesimis dalam dirinya, menghafal Al-Quran hanya untuk memenuhi syarat agar terpenuhinya 


\section{U. N. Saeful}

nilai praktik tilawah saja, selain dari itu faktor lingkungan pun menjadi salah satu faktor tidak adanya motivasi untuk menghafal Al-Quran. Contohnya jika ada teman khususnya teman sekelompok yang pemalas maka mereka akan terbawa malas, dan juga faktor latar belakang pendidikan seperti latar belakang pendidikan dari SMA atau SMK yang bukan berbasis sekolah Islami pun menjadi alasan tidak adanya motivasi untuk menghafal Al-Quran.

Berdasarkan studi awal tersebut tampak bahwa ada indikasi perbedaan respon mahasiswa terhadap bimbingan praktik tilawah yang tampak pada perbedaan motivasi mahasiswa dalam menghafal Al-Quran. Mengingat demikian, fenomena tersebut menarik untuk diteliti. Maka, peneliti mengambil judul penelitian "Pengaruh Bimbingan Praktik Tilawah terhadap Motivasi Menghafal Al-Quran".

Penelitian ini dilaksanakan terhadap mahasiswa angkatan 2014 di Jurusan Bimbingan Konseling Islam Fakultas Dakwah dan Komunikasi UIN Sunan Gunung Djati Bandung Jl. A.H. Nasution No. 105 Cibiru Bandung. Alasan memilih tempat ini yaitu karena lokasi penelitian mudah dijangkau sehingga memudahkan dalam pengambilan data dan juga setelah melaksanakan observasi sejak bulan April 2017 mendapatkan hasil bahwa mahasiswa Jurusan Bimbingan Konseling Islam angkatan 2014 memiliki keaktifan yang cukup unggul dalam menghafal Al-Quran dibandingkan dengan angkatan lainnya sehingga memudahkan peneliti dalam mendapatkan data mengenai motivasi menghafal Al-Quran mahasiswa Jurusan Bimbingan Konseling Islam angkatan 2014 dalam pelaksanaan bimbingan praktik tilawah.

Penelitian terdahulu terkait judul antara lain sebagai berikut: Penelitian Haryanto, E., Cahyana, R. (2015:1) berjudul Pengembangan Aplikasi Mutabaah Tahfidz Alquran Untuk Mengevaluasi Hafalan. Penelitian Nashir, A., Halib, A. (2016: 1) berjudul Sistem Pembinaan Halaqah Terhadap Kecerdasan Emosional Santri Di Markaz Tahfidz Alquran Al-Birr. Penelitian Bahrudin, B., Kumaidi,K. (2014:1) berjudul Model Asesmen Musabaqah Tilawah Al-Quran (Mtq) Cabang Tilawah. Penelitian Abdussalam, A., Fakhruddin, A., Nursahid, Rofik.( 2015) berjudul Program Pembelajaran Tilawah Al-Quran Pada Pondok Pesantren AlQuran Al-Falah Cicalengka Bandung (Studi Deskriptif Tentang Program Pembelajaran Tilawah Al-Quran Tahun 2015:1) Penelitian Untomo, dkk.(2015:1) berjudul Fungsi Rumah Tilawah Ikhwah Rasul Dalam Penanaman Nilai-Nilai Keislaman (Studi Pada Mahasiswa Universitas Negeri Semarang).

Begitu pula penelitian yang dilakukan oleh Marlina (2018) mengungkapkan bahwa pemberian reward yang dilakukan oleh guru kelas kepada siswanya dalam meningkatkan motivasi hafalan surat pendek Al-Quran pada anak di TKA Darussalam Pameungpeuk. Sejalan dengan itu, Hijriyanti (2018) mengungkapkan 
bahwa sebagai pembimbing, usaha yang dilakukan yaitu: membantu santri ketika kesulitan dalam menyetorkan hapalan $\mathrm{Al}$ Qur'an, memperhatikan problem yang dihadapi santri dalam menghapal Al-Qur'an, dan memberi saran. Sedangkan sebagai motivator, usaha yang dilakukan yaitu: mengadakan semaan, memberi wejangan-wejangan.

Penelitian penelitian terdahulu berbeda objek kajian meskipun tentang sama sama tentang tilawah Alquran dan tahfidz. Penelitian yang dilakukan peneliti lebih ke proses bimbingan yang dilakukan dan melihat pengaruhnya terhadap motifasi menghapal.

Pertanyaan penelitian dalam penelitian ini yaitu: Pertama, Bagaimana proses bimbingan praktik tilawah mahasiswa Jursan Bimbingan Konseling Islam angkatan 2014? Kedua, Bagaimana motivasi menghafal Al-Quran mahasiswa Jursan Bimbingan Konseling Islam angkatan 2014? Ketiga, Seberapa berpengaruh bimbingan praktik tilawah terhadap motivasi menghafal Al-Quran mahasiswa Jursan Bimbingan Konseling Islam angkatan 2014?

Adapun metode penelitian dalam penelitian ini yaitu metode kuantitatif pendekatan asosiatif yaitu penelitian yang bertujuan untuk mengetahui pengaruh ataupun juga hubungan antara dua variabel atau lebih (Sugiyono, 2013: 11).

\section{LANDASAN TEORITIS}

Teori yang dijadikan landasan dalam penelitian ini adalah teori bimbingan praktik tilawah dan motivasi menghafal Al-Quran.

Rochman Natawidjaja (dalam Yusuf L.N dan Nurihsan, 2014: 6) mengartikan bimbingan sebagai suatu proses pemberian bantuan kepada individu yang dilakukan secara berkesinambungan, supaya individu tersebut dapat memahami dirinya, sehingga dia sanggup mengarahkan dirinya dan dapat bertindak secara wajar, sesuai dengan tuntutan dan keadaan lingkungannya. Dengan demikian, bimbingan membantu individu mencapai perkembangan diri secara optimal sebagai makhluk sosial.

Menurut Kamus Psikologi yang dimaksud dengan practice (praktik) adalah "pengulangan suatu perbuatan atau fungsi tingkah laku, untuk meningkatkan tujuan fungsi atau sesuatu yang menjadi kebiasaan atau suatu hal yang khas" (Chaplin, 2014: 378). Sedangkan tilawah menurut Kamus Besar Bahasa Indonesia adalah "pembacaan (ayat Al-Quran) dengan baik dan indah" (Pusat Bahasa, 2014: 1462).

Adapun maksud praktik tilawah dalam penelitian ini adalah bagian dari proses pembekalan penguasaan pesan dakwah yang diturunkan dari sumbernya, yakni Al-Quran dan Hadits dalam standar minimal, dan pemberian kunci-kunci praktis dalam mencari dan mengkategorikan pesan dakwah sesuai dengan 


\section{U. N. Saeful}

kebutuhan dasar mad'u. Praktik tilawah meliputi kegiatan pembimbingan bacatulis dan tahfidh Al-Quran dan Hadits berikut simulasi dan penguasaan yang terkait dengan penguasaan pesan dakwah yang diturunkan dari Al-Quran dan Hadits (Panduan Penyelenggaraan Praktik Tilawah, 2015: 5).

Dari pengertian tersebut, dapat disimpulkan bahwa bimbingan praktik tilawah adalah proses pemberian bantuan kepada individu secara sistemasis dan berkesinambungan dalam bentuk kegiatan baca-tulis tahfidh Al-Quran dan Hadits serta simulasi dan penguasaan pesan dakwah yang diturunkan dari Al-Quran dan Hadits.

Tujuan praktik tilawah yaitu untuk meningkatkan kualitas mahasiswa Fakultas Dakwah dan Komunikasi dalam memahami dan menguasai pesan dakwah yang bersumber dari Al-Quran dan Hadits serta terampil menggunakannya dalam proses dakwah (Panduan Penyelenggaraan Praktik Tilawah, 2015: 6).

Dalam pelaksanaannya, perlu diperhatikan unsur-unsur yang terdapat dalam bimbingan karena kegiatan bimbingan dapat dikatakan berhasil jika terdapat unsur-unsur bimbingan di dalamnya. Menurut Enjang AS dan Aliyudin (dikutip dari Karlina, 2016: 15) bahwa unsur-unsur bimbingan terdiri dari pembimbing, klien/terbimbing, metode, materi, dan media.

Pertama, pembimbing yaitu orang yang menyampaikan materi atau pesan. Dalam proses bimbingan, pembimbing berperan sebagai orang yang mengarahkan serta mengatur jalannya proses bimbingan. Peranan pembimbing dalam Islam adalah sebagai juru penerang dan pemberi petunjuk ke arah kebenaran (mubayyin), juru pengingat (mudzakkir), juru penghibur (mubasyir) hati yang luka lara, serta penyampai (mubaligh) pesan-pesan wahyu, perilaku sehariharinya mencerminkan contoh teladan yang baik (uswatun hasanal) di tengah umatnya (Miharja, 2013: 20).

Kedua, klien yaitu setiap individu yang diberikan bantuan profesional oleh seorang pembimbing/konselor atas permintaan dirinya sendiri atau orang lain (Willis, 2014: 111). Klien yang dimaksud dalam penelitian ini adalah mahasiswa yang telah melaksanakan bimbingan praktik tilawah pada semester ganjil (semester III) dengan batas minimal frekuensi tatap muka pelaksanaan praktik tilawah sebanyak 12 kali pertemuan (Panduan Penyelenggaraan Praktik Tilawah, 2015: 13).

Ketiga, materi yaitu isi pesan (massage) yang disampaikan oleh seorang pembimbing kepada klien. Dalam penyusunan materi bimbingan didasarkan pada tujuan bimbingan yang disesuaikan dengan kebutuhan klien. Secara global, materi bimbingan dapat diklasifikasikan menjadi tiga hal pokok yaitu akidah, ibadah, dan akhlak (Riyadi, 2013: 32-36). Berkaitan dengan penelitian ini, materi bimbingan praktik tilawah di Fakultas Dakwah dan Komunikasi disajikan lebih 
proporsional. Terdapat beberapa materi pokok dalam kegiatan bimbingan praktik tilawah (Panduan Penyelenggaraan Praktik Tilawah, 2015: 9) di antaranya adalah: 1) Membaca dan menulis ayat-ayat Al-Quran; 2) Membaca dan menulis Hadits; 3) Menghafal ayat-ayat Al-Quran dan terjemahannya; 4) Menghafal Hadits-Hadits dan terjemahannya; 5) Membaca, menterjemahkan, dan menjelaskan teks kitab materi dakwah; 6) Menggunakan Mu'jam Al-Quran dalam mencari ayat-ayat bahan dakwah; 7) Menyusun naskah khitabah dalam bentuk Satuan Materi Ceramah (SMC).

Keempat, metode yaitu suatu rangkaian yang sistematis dan merujuk kepada tata cara yang sudah dibina berdasarkan rencana yang pasti, mapan, dan logis. Dalam Al-Quran metode bimbingan atau metode dakwah merujuk pada QS. AnNahl: 125. Adapun metode bimbingan praktik tilawah di antaranya adalah metode tajwid takwin, metode penugasan, dan metode simulasi (Panduan Penyelenggaraan Praktik Tilawah, 2015: 12).

Kelima, media yaitu sarana atau alat untuk berkomunikasi antara sender (yang menyampaikan pesan) dan audience (penerima pesan) (Noor, 2015: 11). Dalam penelitian ini media yang dimaksud merupakan sarana bimbingan praktik tilawah yaitu semua yang dapat dijadikan alat dalam proses bimbingan praktik tilawah seperti gedung tempat bimbingan (ruang kuliah), masjid, buku-buku, alat peraga, dan lain-lain.

Ramayulus (dalam Arifin, 2015: 132) mendefinisikan bahwa motivasi (motivate dan metion) adalah istilah yang lebih umum digunakan untuk menggantikan tema "motif-motif" yang berarti gerakan yang dilakukan oleh manusia, dapat berarti rangsangan atau dorongan untuk bertingkah laku.

Menghafal Al-Quran adalah suatu proses belajar dan mengingat kembali kalam Allah yang diwahyukan kepada Nabi Muhammad Saw sebagai mukjizat yang pernah dibaca dan mencoba menyimpannya di dalam ingatan (Adawiyah, 2016: 29-30). Dengan demikian motivasi menghafal Al-Quran adalah kekuatan rangsangan atau dorongan dalam diri individu untuk mengingat kembali AlQuran agar menjaga dari kelupaan, baik secara keseluruhan maupun sebagainya.

Menurut Aritonang (dikutip dari Kasyfulbayan, 2017: 20-21) dilihat dari motivasi belajar, bahwa motivasi belajar meliputi beberapa dimensi yaitu: 1) Ketekunan dalam belajar; 2) Ulet dalam menghadapi kesulitan; 3) Minat dan ketajaman perhatian dalam belajar; 4) Berprestasi dalam belajar; dan 5) Mandiri dalam belajar.

Aspek motivasi menghafal Al-Quran merupakan ciri-ciri dari individu yang memiliki motivasi tinggi untuk menghafal Al-Quran. Adapun ciri-ciri individu 


\section{U. N. Saeful}

yang memiliki motivasi menghafal Al-Quran yaitu memiliki perencanaan dalam aktivitas menghafal Al-Quran, memiliki pencapaian tujuan yang diinginkan, memiliki kesadaran untuk menghafal Al-Quran, menghargai dan menerima pembimbing yang mengajarkan hafalan Al-Quran, serta memiliki rasa ingin tahu yang tinggi dalam proses menghafal Al-Quran (dikutip dari Kasyfulbayan, 2017: 21).

Adapun yang mempengaruhi motivasi menghafal Al-Quran di antaranya yaitu faktor pendukung dan faktor penghambat dalam menghafal Al-Quran (Adawiyah, 2016: 32). Faktor pendukung dalam menghafal Al-Qurandi antaranya yaitu usia yang ideal, manajemen waktu, serta tempat yang dipilih untuk menghafal Al-Quran. Sedangkan faktor yang menjadi penghambat dalam proses menghafal Al-Quran yaitu karena faktor problematika dakhiliyah (intern) seperti: 1) Terlalu sibuk dengan dunianya. 2) Tidak merasakan kenikmatan Al-Quran, besar kecilnya kenikmatan membaca Al-Quran sangat tergantung pada kualitas keimanan dan ketaqwaan pembacanya kepada Allah Swt. 3) Tidak sabar, malas, dan berputus asa. Problematika khorijyah (ekstern) seperti: 1) tidak dapat membaca dengan baik, 2) tidak dapat mengatur waktu, (3) ayat-ayat sulit (tasyabubul ayat), 4) tidak ada muwazzih (pembimbing), dan sebagainya (Adawiyah, 2016: 36).

\section{HASIL DAN PEMBAHASAN}

Seiring dengan perubahan IAIN Sunan Gunung Djati Bandung menjadi Universitas Islam Negeri (UIN) Sunan Gunung Djati Bandung, maka berdasarkan Peraturan Presiden Republik Indonesia Nomor 57 Tahun 2005 Fakultas Dakwah pun berubah menjadi Fakultas Dakwah dan Komunikasi. Adapun awal berdirinya Jurusan Bimbingan dan Penyuluhan Islam yang sekarang menjadi Jurusan Bimbingan Konseling Islam (BKI) yaitu pada tahun 1993 bersamaan dengan berdirinya Fakultas Dakwah. Mahasiswa angkatan pertama Jurusan BPI/BKI berjumlah 80 orang (Panduan Akademik, 2014: 4). Tujuan dari Jurusan BKI yaitu siap mencetak tenaga profesional sebagai pembimbing (konselor, terapis) dan penyuluh Islam yang banyak dibutuhkan dalam berbagai aspek kehidupan. Oleh karena itu, keahlian jurusan BKI diorientasikan kepada keahlian teoritik dan keahlian praktik di bidang konselor, terapis, dan penyuluh Islam.

Adapun program atau kegiatan yang wajib diikuti oleh setiap mahasiswa agar mendapatkan nilai sebagai syarat lulus di antaranya yaitu mengikuti kegiatan praktik ibadah pada semester I dan mengikuti kegiatan praktik tilawah pada semester III. Kegiatan tersebut, sebagai salah satu persayaratan untuk mengikuti sidang munaqasyah atau yang lebih dikenal dengan sidang akhir. Mengingat demikian, kaitannya dengan penelitian ini yaitu mengenai praktik tilawah, dari 
hasil penelitian dapat diketahui bahwa dalam pelaksanaan praktik tilawah mahasiswa dibagi menjadi beberapa kelompok dan dibimbing oleh seorang dosen pembimbing ahli. Pelaksanaan bimbingan praktik tilawah pada semester ganjil (semester III) dengan batas minimal frekuensi tatap muka pelaksanaan praktik tilawah sebanyak 12 kali pertemuan. Kegiatan praktik tilawah dilaksanakan secara intensif selama delapan minggu (Panduan Penyelenggaraan Praktik Tilawah, 2015: 13).

Tugas mahasiswa atau peserta praktik tilawah yaitu berkewajiban memenuhi persyaratan administrasi akademik serta berkewajiban mengikuti kegiatan praktik tilawah sesuai jadwal yang telah ditentukan dengan pembimbing praktik tilawah (Panduan Penyelenggaraan Praktik Tilawah, 2015: 8). Materi yang dibahas dalam pelaksanaan praktik tilawah di antaranya adalah: membaca dan menulis ayat-ayat Al-Quran, membaca dan menulis hadits, menghafal ayat-ayat Al-Quran, dan lain-lain. Salah satu materi yang membuat sebagian mahasiswa merasa terbebani yaitu menghafal ayat-ayat Al-Quran. Terdapat beberapa pembimbing praktik tilawah yang hanya menugaskan untuk menghafal ayat-ayat Al-Quran yang berkaitan dengan dakwah tetapi adapula beberapa pembimbing praktik tilawah yang menugaskan untuk menghafal ayat-ayat Al-Quran juz 30.

Hasil penelitian ini menemukan hasil proses bimbingan praktik tilawah, motivasi menghafal Al-Quran serta pengaruh praktik tilawah terhadap motivasi menghafal Al-Quran mahasiswa Jurusan Bimbingan Konseling Islam angkatan 2014.

\section{Realitas Bimbingan Praktik Tilawah Mahasiswa Jurusan Bimbingan Konseling Islam Angkatan 2014}

Untuk mengetahui bimbingan praktik tilawah di Jurusan Bimbingan Konseling Islam angkatan 2014, maka dilakukan penyebaran angket sebanyak 22 item dengan 14 item pernyataan positif dan 8 item pernyataan negatif yang disebarkan kepada 64 responden mahasiswa Jurusan Bimbingan Konseling Islam. 22 item tersebut berbentuk angket dengan alternatif jawaban yaitu SS (Sangat Setuju), S (Setuju), N (Netral), TS (Tidak Setuju), STS (Sangat Tidak Setuju). Setiap alternatif jawaban diberi skor tertentu, untuk item pernyataan positif diberi skor $\mathrm{SS}=5, \mathrm{~S}=4, \mathrm{~N}=3$, TS $=2$, STS $=1$ sedangkan untuk item pernyataan negatif diberi skor $\mathrm{SS}=1, \mathrm{~S}=2, \mathrm{~N}=3$, TS $=4$, STS $=5$. Penilaian tersebut mengacu pada rentang nilai terendah 1 dan nilai tertinggi 5.

Terdapat penentuan kategorisasi skala perhitungan hasil kuesioner yang telah diisi oleh responden, jumlah ideal untuk item pernyataan positif yaitu SS (Sangat Setuju) $5 \times 64=320, S$ (Setuju) $4 \times 64=256, N$ (Netral) $3 \times 64=192$, TS (Tidak Setuju) $2 \times 64=128$, STS (Sangat Tidak Setuju) $1 \times 64=64$. 


\section{U. N. Saeful}

Sedangkan untuk item pernyataan negatif yaitu, SS (Sangat Setuju) $1 \times 64=64, \mathrm{~S}$ (Setuju) $2 \times 64=128$, N (Netral) $3 \times 64=192$, TS (Tidak Setuju) $4 \times 64=256$, STS (Sangat Tidak Setuju) 5 × $64=320$. Kategorisasi skala perhitungan nilai bimbingan praktik tilawah, diinterpretasikan menggunakan skala berikut:

Tabel 1.

Interpretasi Skala Perhitungan Bimbingan Praktik Tilawah

\begin{tabular}{cccc}
\hline Rentang Skor & Persentase Skor & Interpretasi & \\
\cline { 1 - 3 } $257-320$ & $80-100 \%$ & Sangat Tinggi & B \\
$193-256$ & $60-79 \%$ & Tinggi & arkan \\
$129-192$ & $40-59 \%$ & Cukup & kuesi \\
$65-128$ & $20-39 \%$ & Rendah & oner \\
$0-64$ & $0-19 \%$ & Sangat Rendah & yang \\
telah
\end{tabular}

disebarkan kepada 64 responden mahasiswa jurusan Bimbingan Konseling Islam, pada kuesioner bimbingan praktik tilawah (variabel $\mathrm{X}$ ) peneliti memberikan pernyataan yang berkaitan dengan bimbingan praktik tilawah. Adapun hasil dari olah data perhitungan peritem variabel X (bimbingan praktik tilawah), dihasilkan nilai rata-rata bimbingan praktik tilawah sebesar 80\% termasuk pada skala sangat tinggi. Untuk lebih jelasnya mengenai bimbingan praktik tilawah mahasiswa Jurusan Bimbingan Konseling Islam angkatan 2014 dapat dilihat pada tabel berikut:

Tabel 2.

Nilai Rata-Rata Variabel X (Bimbingan Praktik Tilawah)

\begin{tabular}{lccc}
\hline \multicolumn{1}{c}{ PERNYATAAN } & $\begin{array}{c}\text { Jumlah } \\
\text { Kumulatif }\end{array}$ & $\begin{array}{c}\text { Nilai } \\
\mathbf{( \% )}\end{array}$ & Kriteria \\
\hline $\begin{array}{l}\text { Pembimbing tilawah menurut saya ahli dalam } \\
\text { tilawah }\end{array}$ & 274 & $85 \%$ & $\begin{array}{c}\text { Sangat } \\
\text { Tinggi }\end{array}$ \\
$\begin{array}{l}\text { Pembimbing memilih tempat bimbingan } \\
\text { praktik tilawah yang nyaman }\end{array}$ & 263 & $82 \%$ & $\begin{array}{l}\text { Sangat } \\
\text { Tinggi }\end{array}$ \\
$\begin{array}{l}\text { Pembimbing memahami tentang cara-cara } \\
\text { menghafal Al-Quran }\end{array}$ & 271 & $84 \%$ & $\begin{array}{l}\text { Sangat } \\
\text { Tinggi }\end{array}$ \\
$\begin{array}{l}\text { Pembimbing memberikan pembekalan dalam } \\
\text { pembentukan kader da'i }\end{array}$ & 247 & $77 \%$ & Tinggi \\
$\begin{array}{l}\text { Pembimbing memahami kemampuan } \\
\text { mahasiswa saat bimbingan praktik tilawah }\end{array}$ & 269 & $84 \%$ & $\begin{array}{l}\text { Sangat } \\
\text { Tinggi }\end{array}$ \\
Saya melaksanakan bimbingan praktik tilawah & 252 & $78 \%$ & Tinggi
\end{tabular}


dengan tepat

Saya berusaha aktif saat bimbingan praktik tilawah

257

Saya senantiasa berdiskusi untuk memahami materi praktik tilawah

Saya berusaha mengingat hadits-hadits yang telah saya tulis saat bimbingan praktik tilawah

Saya berusaha menghafal ayat-ayat Al-Quran saat bimbingan praktik tilawah praktik tilawah

Saya menggunakan mu’jam Al-Quran dalam mencari ayat-ayat bahan dakwah saat bimbingan praktik tilawah

Saya melaksanakan praktik khitabah (ceramah) saat bimbingan praktik tilawah

Saya mampu menjelaskan isi dari teks kitab materi dakwah yang sudah saya terjemahkan saat bimbingan praktik tilawah

Menurut saya pembimbing hanya

berkomunikasi satu arah dengan mahasiswa saat bimbingan praktik tilawah

Pembimbing menggunakan buku sebagai media praktik tilawah seperlunya

Pembimbing menugaskan mahasiswa untuk menghafal Al-Quran semaunya

Saya melaksanakan bimbingan praktik tilawah lebih dari waktu yang ditentukan

Saya kurang disiplin waktu saat mengikuti bimbingan praktik tilawah

Saya sukar membuat naskah ceramah saat bimbingan praktik tilawah

Saya mencoba menghindari pembahasan yang tidak dimengerti saat melaksanakan bimbingan praktik tilawah

Saya membutuhkan waktu cukup lama ketika menghafal hadits saat bimbingan praktik tilawah
Saya rajin membaca Al-Quran saat bimbingan

\begin{tabular}{|c|c|}
\hline 257 & $80 \%$ \\
\hline 248 & $77 \%$ \\
\hline 259 & $80 \%$ \\
\hline 262 & $81 \%$ \\
\hline 283 & $88 \%$ \\
\hline 283 & $88 \%$ \\
\hline 257 & $80 \%$ \\
\hline 227 & $70 \%$ \\
\hline 246 & $76 \%$ \\
\hline 257 & $80 \%$ \\
\hline 262 & $81 \%$ \\
\hline 230 & $71 \%$ \\
\hline 255 & $79 \%$ \\
\hline 258 & $80 \%$ \\
\hline 277 & $86 \%$ \\
\hline 262 & $81 \%$ \\
\hline
\end{tabular}

Irsyad : Jurnal Bimbingan, Penyuluhan, Konseling, dan Psikoterapi Islam 7(2) (2019) 225-248 


\begin{tabular}{|c|}
\hline Rata-rata \\
\hline
\end{tabular}

Sumber: (Data Hasil Pengolahan Angket, April 2018)

Berdasarkan hasil rata-rata presentase kriteria penilaian mengenai bimbingan praktik tilawah sebesar $80 \%$ yang berarti bahwa bimbingan praktik tilawah mahasiswa jurusan Bimbingan Konseling Islam angkatan 2014 (variabel $\mathrm{X})$ termasuk kategori sangat tinggi. Hal ini menunjukkan bahwa antusiasme mahasiswa jurusan Bimbingan Konseling Islam angkatan 2014 cukup tinggi dalam mengikuti proses pelaksanaan bimbingan praktik tilawah. Salah satu faktor kesuksesan dalam pelaksanaan bimbingan praktik tilawah ini yaitu cara yang dilakukan oleh pembimbing dalam melaksanakan bimbingan.

Seperti halnya dalam pelaksanaan dakwah, menurut Aliyudin (2010: 2) bahwa kesuksesan dakwah sangat ditentukan oleh bagaimana dakwah itu dilaksanakan. Tata cara dalam berdakwah termasuk pengemasan materi, sikap, dan cara penyampaian materi dakwah menjadi lebih penting dari materi dakwahnya. Unsur-unsur bimbingan juga dapat menentukan berhasil atau tidaknya pelaksanaan bimbingan tersebut maka dari itu dalam pelaksanaan bimbingan perlu adanya unsur-unsur bimbingan terdiri dari pembimbing, klien/terbimbing, metode, materi, dan media (Enjang AS dan Aliyudin dikutip dari Karlina, 2016: 15). Proses adjustment/penyesuaian terhadap konseli atau mad'u pun dapat mempengaruhi keberhasilan pelaksanaan bimbingan.

Adapun adjustment dapat dilakukan dengan cara: 1) Autoplastis, yaitu melakukan penyesuaian dengan cara mengubah diri sendiri. Dalam konteks dakwah yaitu dai/pembimbing mengubah perilaku dan keadaannya sendiri sehingga interaksi antara pembimbing dan konseli berjalan dengan baik. 2) Alloplastis, yaitu melakukan penyesuaian dengan cara mengubah lingkungan. Dalam konteks dakwah, dai/pembimbing berupaya mengubah lingkungannya termasuk mengubah konseli sehingga interaksi antara pembimbing dan konseli berjalan dengan baik. 3) Allo-autoplastis, yaitu melakukan penyesuaian dengan cara mengubah diri dan lingkungannya. Dalam konteks dakwah, pembimbing berupaya mengubah dirinya sendiri serta lingkungannya termasuk konselinya sehingga interaksi antara pembimbing dan konseli berjalan dengan baik (Ardi, 2015: 80-84). Dari hasil penelitian ini, dapat diketahui bahwa pembimbing praktik tilawah menggunakan cara allo-autoplastis yairu berupaya mengubah diri, lingkungan, serta keadaan mahasiswa sebagai konseli agar dapat melaksanakan bimbingan praktik tilawah dengan baik.

\section{Realitas Motivasi Menghafal Al-Quran Mahasiswa Jurusan Bimbingan Konseling Islam Angkatan 2014}


Untuk mengetahui motivasi menghafal Al-Quran mahasiswa jurusan Bimbingan Konseling Islam angkatan 2014, maka dilakukan penyebarakan angket sebanyak 22 item dengan 14 item pernyataan positif dan 8 item pernyataan negatif yang disebarkan kepada 64 responden mahasiswa Jurusan Bimbingan Konseling Islam. Adapun dari hasil kuesioner yang telah disebarkan tersebut, menghasilkan nilai rata-rata motivasi menghafal Al-Quran sebesar 78\% termasuk pada skala tinggi. Untuk lebih jelasnya mengenai motivasi menghafal Al-Quran mahasiswa Jurusan Bimbingan Konseling Islam angkatan 2014 dapat dilihat pada tabel berikut:

Tabel 3.

Nilai Rata-Rata Variabel Y (Motivasi Menghafal Al-Quran)

\begin{tabular}{|c|c|c|c|}
\hline PERNYATAAN & $\underset{\text { Kumulatif }}{\text { Jumlah }}$ & $\begin{array}{c}\text { Nilai } \\
(\%)\end{array}$ & Kriteria \\
\hline $\begin{array}{l}\text { Saya senang mencari informasi baru tentang } \\
\text { cara menghafal Al-Quran }\end{array}$ & 257 & $80 \%$ & $\begin{array}{l}\text { Sangat } \\
\text { Tinggi }\end{array}$ \\
\hline $\begin{array}{l}\text { Saya berusaha mengikuti perkembangan dari } \\
\text { berbagai media untuk memperluas wawasan } \\
\text { tentang menghafal Al-Quran }\end{array}$ & 258 & $80 \%$ & $\begin{array}{l}\text { Sangat } \\
\text { Tinggi }\end{array}$ \\
\hline Saya memiliki minat menghafal Al-Quran & 269 & $84 \%$ & $\begin{array}{l}\text { Sangat } \\
\text { Tinggi }\end{array}$ \\
\hline $\begin{array}{l}\text { Saya membuat jadwal untuk menghafal ayat } \\
\text { Al-Quran setelah bimbingan praktik tilawah }\end{array}$ & 223 & $69 \%$ & Tinggi \\
\hline $\begin{array}{l}\text { Saya menyempatkan waktu untuk menghafal } \\
\text { Al-Quran satu minggu sekali }\end{array}$ & 232 & $72 \%$ & Tinggi \\
\hline Saya yakin saya mampu menghafal Al-Quran & 283 & $88 \%$ & $\begin{array}{l}\text { Sangat } \\
\text { Tinggi }\end{array}$ \\
\hline $\begin{array}{l}\text { Saya bersikap tenang dalam menghafal Al- } \\
\text { Quran walaupun terasa susah }\end{array}$ & 266 & $83 \%$ & $\begin{array}{l}\text { Sangat } \\
\text { Tinggi }\end{array}$ \\
\hline $\begin{array}{l}\text { Saya berusaha menghafal Al-Quran dengan } \\
\text { sungguh-sungguh }\end{array}$ & 267 & $84 \%$ & $\begin{array}{l}\text { Sangat } \\
\text { Tinggi }\end{array}$ \\
\hline $\begin{array}{l}\text { Saya berani untuk mencoba hal-hal baru } \\
\text { yang menurut orang lain memerlukan } \\
\text { keberanian }\end{array}$ & 257 & $80 \%$ & $\begin{array}{l}\text { Sangat } \\
\text { Tinggi }\end{array}$ \\
\hline $\begin{array}{l}\text { Jika cara belajar saya salah dalam menghafal } \\
\text { Al-Quran, saya siap untuk menerima } \\
\text { kritikan }\end{array}$ & 277 & $86 \%$ & $\begin{array}{l}\text { Sangat } \\
\text { Tinggi }\end{array}$ \\
\hline
\end{tabular}


Saya merasa senang jika dapat mengambil keputusan yang menurut orang lain berisiko

Saya berusaha untuk konsentrasi ketika sedang menghafal Al-Quran

Saya berusaha meminta pendapat orang lain ketika saya mengalami kesulitan dalam menghafal Al-Quran

Saya berusaha seoptimal mungkin ketika menghafal Al-Quran

Saya membandingkan prestasi menghafal AlQuran saya dengan teman saya

Saya kurang percaya diri saat menghafal AlQuran

Menghafal Al-Quran membuat ngantuk

Saya leha-leha saat menghafal Al-Quran

Jika terdapat ayat Al-Quran yang sulit dihafal saya memutuskan untuk berhenti menghafalnya

Saya merasa malas menghafal Al-Quran

Saya menyimak informasi baru tentang menghafal Al-Quran seperlunya

Saya mempertahankan pendapat saya jika saya salah dalam menghafal Al-Quran
242

282

262

279

260

220

230

245

215

230

250
$75 \% \quad$ Tinggi

$\begin{array}{ll}88 \% & \text { Sangat } \\ & \text { Tinggi }\end{array}$

$81 \% \quad$ Sangat

Tinggi

Sangat

Tinggi

Sangat

Tinggi

68\% Tinggi

70\% Tinggi

$71 \% \quad$ Tinggi

$72 \% \quad$ Tinggi

$76 \% \quad$ Tinggi

67\% Tinggi

$71 \% \quad$ Tinggi

78\% Tinggi

Sumber: (Data Hasil Pengolahan Angket, April 2018)

Berdasarkan hasil pengolahan data tersebut menunjukkan bahwa motivasi menghafal Al-Quran mahasiswa jurusan Bimbingan Konseling Islam angkatan 2014 memiliki hasil rata-rata presentase sebesar 78\% yang berarti motivasi menghafal Al-Quran mahasiswa jurusan Bimbingan Konseling Islam angkatan 2014 termasuk kategori tinggi. Hal ini menunjukkan bahwa mahasiswa jurusan Bimbingan Konseling Islam angkatan 2014 memiliki motivasi tinggi dalam menghafal Al-Quran. Adapun ciri-ciri dari individu yang memiliki motivasi menghafal Al-Quran yaitu memiliki perencanaan dalam aktivitas menghafal AlQuran, memiliki pencapaian tujuan yang diinginkan, memiliki kesadaran untuk menghafal Al-Quran, menghargai dan menerima pembimbing yang mengajarkan hafalan Al-Quran, serta memiliki rasa ingin tahu yang tinggi dalam proses menghafal Al-Quran (dikutip dari Kasyfulbayan, 2017: 21). Dengan demikian, 
maka mahasiswa jurusan Bimbingan Konseling Islam 78\% memiliki motivasi menghafal Al-Quran dengan ciri-ciri tersebut.

\section{Pengaruh Bimbingan Praktik Tilawah terhadap Motivasi Menghafal Al- Quran Mahasiswa Jurusan Bimbingan Konseling Islam Angkatan 2014}

Pengaruh bimbingan praktik tilawah terhadap motivasi menghafal Al-Quran dapat dilihat dari adanya keterkaitan antara variabel X (Bimbingan Praktik Tilawah) dan variabel Y (Motivasi Menghafal Al-Quran). Pengaruh dari kedua variabel tersebut dapat dilihat dari hasil pengolahan data SPSS (Statistical Pakcage for Social Science) 22.0 sebagai berikut:

Uji validitas dilakukan agar setiap pernyataan yang diajukan dapat memenuhi syarat validitas sehingga dapat diterima sebagai instrument yang layak digunakan dalam penelitian. Sebuah instrumen dikatakan valid apabila mampu mengukur apa yang diinginkan dan apabila dapat mengungkap data dari variabel yang diteliti secara tepat.

Tabel 4.

Item-Total Statistics

\begin{tabular}{|c|c|c|c|c|c|}
\hline & $\begin{array}{l}\text { Scale Mean if } \\
\text { Item Deleted }\end{array}$ & $\begin{array}{l}\text { Scale Variance } \\
\text { if Item Deleted }\end{array}$ & $\begin{array}{l}\text { Corrected } \\
\text { Item-Total } \\
\text { Correlation }\end{array}$ & $\begin{array}{c}\text { Squared } \\
\text { Multiple } \\
\text { Correlation } \\
\end{array}$ & $\begin{array}{c}\text { Cronbach's } \\
\text { Alpha if Item } \\
\text { Deleted }\end{array}$ \\
\hline $\mathrm{X} 1$ & 84.77 & 83.897 & .471 & . & .864 \\
\hline $\mathrm{X} 2$ & 84.94 & 86.631 & .251 & . & .870 \\
\hline X3 & 84.81 & 83.552 & .492 & . & .863 \\
\hline $\mathrm{X} 4$ & 85.19 & 84.536 & .348 & . & .868 \\
\hline $\mathrm{X} 5$ & 84.84 & 81.531 & .602 & . & .860 \\
\hline X6 & 85.11 & 85.242 & .295 & . & .870 \\
\hline $\mathrm{X} 7$ & 85.03 & 83.332 & .455 & . & .864 \\
\hline $\mathrm{X} 8$ & 85.17 & 83.764 & .515 & . & .863 \\
\hline X9 & 85.00 & 85.460 & .277 & . & .870 \\
\hline $\mathrm{X} 10$ & 84.95 & 80.998 & .584 & . & .860 \\
\hline X11 & 84.63 & 85.571 & .435 & . & .865 \\
\hline $\mathrm{X} 12$ & 84.63 & 82.302 & .569 & . & .861 \\
\hline $\mathrm{X} 13$ & 85.03 & 83.459 & .446 & . & .865 \\
\hline
\end{tabular}


U. N. Saeful

\begin{tabular}{lllllll} 
X14 & 85.50 & 84.063 & .321 &. & .870 & $\begin{array}{c}\text { Uji } \\
\text { Validitas } \\
\text { X15 }\end{array}$ \\
\hline 85.20 & 83.307 & .436 &. & .865 & $\begin{array}{c}\text { Variabel } \\
\text { X }\end{array}$ \\
X16 & 85.03 & 81.459 & .542 &. & .861 & Sumber: \\
X17 & 84.95 & 80.998 & .584 &. & .860 & (Data \\
X18 & 85.45 & 79.363 & .610 &. & .858 & Hasil \\
X19 & 85.06 & 84.980 & .315 &. & .869 & Output \\
X20 & 85.02 & 85.698 & .308 &. & .869 & April \\
X21 & 84.72 & 81.697 & .532 &. & .862 & 2018) \\
X22 & 84.95 & 80.998 & .584 &. & .860 & D \\
\hline
\end{tabular}

menggunakan jumlah responden sebanyak 64 maka $\mathrm{r}$ tabel dapat diperoleh melalui tabel $\mathrm{r}$ product moment pearson dengan df $=\mathrm{n}-2$, maka berlaku kriteria uji: $r_{\text {hitung }}>r_{\text {tabel }}$. $R_{\text {tabel }}$ yang digunakan $=0,2461$, dengan demikian hasil uji validitas dapat diketahui bahwa keseluruhan pernyataan yang terdiri dari 22 item pernyataan bimbingan praktik tilawah (variabel X) X1, X2, X3, X4, X5, ....., X22 tersebut dinyatakan valid.

Tabel 5.

Item-Total Statistics

\begin{tabular}{cccccc}
\hline & $\begin{array}{c}\text { Scale Mean if } \\
\text { Item Deleted }\end{array}$ & $\begin{array}{c}\text { Scale Variance } \\
\text { if Item Deleted }\end{array}$ & $\begin{array}{c}\text { Corrected } \\
\text { Item-Total } \\
\text { Correlation }\end{array}$ & $\begin{array}{c}\text { Squared } \\
\text { Multiple } \\
\text { Correlation }\end{array}$ & $\begin{array}{c}\text { Cronbach's } \\
\text { Alpha if Item } \\
\text { Deleted }\end{array}$ \\
\hline Y1 & 82.16 & 121.975 & .598 & .707 & .908 \\
Y2 & 82.14 & 124.186 & .591 & .670 & .908 \\
Y3 & 81.97 & 121.174 & .714 & .663 & .906 \\
Y4 & 82.69 & 121.552 & .523 & .661 & .910 \\
Y5 & 82.55 & 121.776 & .491 & .658 & .910 \\
Y6 & 81.75 & 123.524 & .598 & .746 & .908 \\
Y7 & 82.02 & 120.841 & .663 & .727 & .906 \\
Y8 & 82.00 & 120.159 & .626 & .634 & .907 \\
Y9 & 82.16 & 124.197 & .517 & .773 & .909 \\
Y10 & 81.84 & 121.658 & .621 & .714 & .907 \\
Y11 & 82.39 & 125.289 & .433 & .552 & .911 \\
Y12 & 81.77 & 124.246 & .660 & .839 & .907
\end{tabular}




\begin{tabular}{|c|c|c|c|c|c|c|}
\hline $\begin{array}{c}\text { Uji } \\
\text { Validitas }\end{array}$ & Y13 & 82.08 & 125.978 & .394 & .447 & .912 \\
\hline \multirow{2}{*}{$\begin{array}{c}\text { Variabel } \\
\text { Y }\end{array}$} & Y14 & 81.81 & 124.885 & .651 & .828 & .908 \\
\hline & Y15 & 82.11 & 122.194 & .556 & .629 & .909 \\
\hline \multirow{5}{*}{$\begin{array}{l}\text { Sumber: } \\
\text { (Data } \\
\text { Hasil } \\
\text { Output } \\
\text { SPSS, } \\
\text { April } \\
2018 \text { ) }\end{array}$} & Y16 & 82.73 & 122.738 & .461 & .525 & .911 \\
\hline & Y17 & 82.63 & 121.889 & .527 & .674 & .909 \\
\hline & Y18 & 82.58 & 124.184 & .489 & .697 & .910 \\
\hline & Y19 & 82.55 & 120.188 & .626 & .616 & .907 \\
\hline & $\mathrm{Y} 20$ & 82.34 & 121.340 & .591 & .590 & .908 \\
\hline \multicolumn{2}{|c|}{$R_{t a b}, \mathrm{Y} 21$} & 82.78 & 126.459 & .379 & .430 & .912 \\
\hline yang & Y22 & 82.58 & 124.851 & .405 & .448 & .912 \\
\hline
\end{tabular}

an $=0,2461$, maka hasil uji validitas dapat diketahui bahwa keseluruhan pernyataan yang terdiri dari 22 item pernyataan motivasi menghafal Al-Quran (variabel Y) Y1, Y2, Y3, Y4, Y5, ....., Y22 tersebut dinyatakan valid.

Reliabilitas alat ukur kuesioner menunjukan sejauh mana instrumen yang digunakan tersebut dapat dipercaya. Menurut Sugiyono (dikutip dari Supriatna, 2016: 105) instrumen yang reliabel adalah instrumen yang apabila digunakan beberapa kali untuk mengukur objek yang sama akan menghasilkan data yang sama. Dengan kata lain, reliabilitas menunjukan konsistensi suatu alat ukur dalam mengukur gejala yang sama.

Tabel 6.

Uji Reliabilitas Variabel X

Reliability Statistics

\begin{tabular}{|c|c|c|}
\hline $\begin{array}{c}\text { Cronbach's } \\
\text { Alpha }\end{array}$ & $\begin{array}{c}\text { Cronbach's } \\
\text { Alpha Based on } \\
\text { Standardized } \\
\text { Items } \\
\end{array}$ & $\mathbf{N}$ of Items \\
\hline .870 & .872 & 22 \\
\hline
\end{tabular}

Sumber: (Data Hasil Output SPSS, April 2018)

Dapat diketahui bahwa Cronbach's Alpha variabel X (bimbingan praktik tilawah) adalah 0,870 . Dengan demikian, maka pernyataan variabel $\mathrm{X}$ (bimbingan praktik tilawah) dapat dikatakan reliabel karena $0,870 \geq 0,70$. 
Tabel 7.

Uji Reliabilitas Variabel Y

Reliability Statistics

\begin{tabular}{|c|c|c|}
\hline $\begin{array}{c}\text { Cronbach's } \\
\text { Alpha }\end{array}$ & $\begin{array}{c}\text { Cronbach's } \\
\text { Alpha Based on } \\
\text { Standardized } \\
\text { Items } \\
\end{array}$ & $\mathbf{N}$ of Items \\
\hline .913 & .917 & 22 \\
\hline
\end{tabular}

Dapat diketahui bahwa Cronbach's Alpha variabel Y (motivasi menghafal Al-Quran) adalah 0,913. Dengan demikian, maka pernyataan variabel Y (motivasi menghafal Al-Quran) dapat dikatakan reliabel karena 0,913 $\geq 0,70$.

Uji normalitas dilakukan untuk mengetahui data berdistribusi normal atau tidak dengan taraf signifikan $\alpha=0.05(5 \%)$ dapat dilihat berdasarkan kriteria Asymp. Sig. (2-tailed) dengan menggunakan uji Sample Kolmogorov-Smirnov. Adapun hipotesis yang diajukan pada uji normalitas yaitu sebagai berikut: $\mathrm{H}_{0}: \mathrm{Pv} \geq 0.005$ maka residual berdistribusi normal. $\mathrm{H}_{1}: \mathrm{Pv} \leq 0.005$ maka residual tidak berdistribusi normal.

Tabel 8.

\section{Uji Normalitas}

One-Sample Kolmogorov-Smirnov Test

\begin{tabular}{lll}
\hline & & $\begin{array}{l}\text { Unstandardize } \\
\text { d Residual }\end{array}$ \\
\hline $\mathrm{N}$ & & 64 \\
Normal Parameters $^{\mathrm{a}, \mathrm{b}}$ & Mean & .0000000 \\
& Std. Deviation 6.11622749 \\
Most Extreme & Absolute & .073 \\
Differences & Positive & .073 \\
& Negative & -.040 \\
Test Statistic & & .073 \\
Asymp. Sig. (2-tailed) & & $.200 \mathrm{c}, \mathrm{d}$ \\
\hline
\end{tabular}
a. Test distribution is Normal.
b. Calculated from data. 

c. Lilliefors Significance Correction.
d. This is a lower bound of the true significance.

Sumber:(Data Hasil Output SPSS, April 2018)

Berdasarkan hasil output SPSS (Statistical Pakcage for Social Science) 22.0 for windows diperoleh $\mathrm{Pv}(0,200) \geq 0.05$. Dengan demikian, $\mathrm{H}_{0}$ diterima karena nilai residual berdistribusi normal maka uji normalitas untuk kuesioner tersebut terpenuhi.

Uji korelasi Pearson Product Moment digunakan untuk mengetahui sejauh mana hubungan dan kontribusi antara bimbingan praktik tilawah dan motivasi menghafal Al-Quran dengan hipotesis: $\mathrm{H}_{0}$ berbunyi tidak terdapat hubungan antara bimbingan praktik tilawah dengan motivasi menghafal Al-Quran dan $\mathrm{H}_{1}$ berbunyi terdapat hubungan antara bimbingan praktik tilawah dengan motivasi menghafal Al-Quran. Taraf signifikan 0,05 dengan kriteria uji $\mathrm{Pv} \geq \alpha \rightarrow \mathrm{H}_{0}$ diterima dan $\mathrm{PV}_{\mathrm{v}} \leq \alpha \rightarrow \mathrm{H}_{0}$ ditolak.

Tabel 9.

Uji Korelasi Pearson Product Moment 


\begin{tabular}{|c|c|c|c|}
\hline & & BimbinganPra & vasiMenghafal \\
\hline & & lawah & AlQuran \\
\hline BimbinganPraktikT & $\Gamma$ Pearson Correlation & 1 & $.850^{* *}$ \\
\hline ilawah & Sig. (2-tailed) & & .000 \\
\hline & $\mathrm{N}$ & 64 & 64 \\
\hline MotivasiMenghafal & 1 Pearson Correlation & $.850^{* *}$ & 1 \\
\hline AlQuran & Sig. (2-tailed) & .000 & \\
\hline & $\mathrm{N}$ & 64 & 64 \\
\hline
\end{tabular}

**. Correlation is significant at the 0.01 level (2-tailed).

Sumber:(Data Hasil Output SPSS, April 2018)

Dari hasil output SPSS versi 22.0 diketahui antara bimbingan praktik tilawah (variabel X) dengan motivasi menghafal Al-Quran (variabel Y) memiliki nilai signifikan $0,000 \leq 0,05$ yang berarti terdapat korelasi yang signifikan. Dengan demikian dapat disimpulkan bahwa terdapat hubungan antara bimbingan praktik tilawah dengan motivasi menghafal Al-Quran.

Tabel 10.

\section{Coefficients $^{\mathrm{a}}$}

\begin{tabular}{|c|c|c|c|c|c|}
\hline \multirow[b]{2}{*}{ Model } & \multicolumn{2}{|c|}{ Unstandardized Coefficients } & \multirow{2}{*}{$\begin{array}{c}\text { Standardized } \\
\text { Coefficients } \\
\text { Beta } \\
\end{array}$} & \multirow[b]{2}{*}{$\mathbf{t}$} & \multirow[b]{2}{*}{ Sig. } \\
\hline & $\mathbf{B}$ & Std. Error & & & \\
\hline (Constant) & -5.825 & 7.297 & & -.798 & .428 \\
\hline $\mathrm{X}$ & 1.033 & .081 & .850 & 12.679 & .000 \\
\hline
\end{tabular}

a. Dependent Variable: $y$

\section{Uji Regresi (Uji t)}

Sumber:(Data Hasil Output SPSS, April 2018)

Dari tabel regresi sederhana tersebut dapat menampilkan uji signifikan dengan uji t yaitu untuk mengetahui apakah ada pengaruh yang signifikan dari bimbingan praktik tilawah (variabel $\mathrm{X}$ ) terhadap motivasi menghafal Al-Quran (variabel $\mathrm{Y}$ ) dengan hipotesis: $\mathrm{H}_{0}$ berbunyi tidak terdapat pengaruh bimbingan praktik tilawah terhadap motivasi menghafal Al-Quran dan $\mathrm{H}_{1}$ berbunyi terdapat pengaruh bimbingan praktik tilawah terhadap motivasi menghafal Al-Quran. Dengan taraf signifikan $\alpha: 0,05$ 
Interpretasinya dapat dilihat pada tabel bahwa nilai $t_{\text {hitung }}=12,679$ dengan nilai signifikan $0,000<0,05$ maka $\mathrm{H}_{0}$ ditolak dan $\mathrm{H}_{1}$ diterima yang berarti terdapat pengaruh yang signifikan bimbingan praktik tilawah terhadap motivasi menghafal Al-Quran.

Koefisien determinasi digunakan untuk mengetahui seberapa besar pengaruh variabel $\mathrm{X}$ (bimbingan praktik tilawah) terhadap variabel $\mathrm{Y}$ (motivasi menghafal Al-Quran) koefisien determinasi dihitung dengan rumus sebagai berikut: $\mathrm{Kd}=\mathbf{r}^{2} \times 100 \%$ (Kd berarti Koefisien Determinasi dan $r^{2}$ berarti Korelasi Product Moment.

Tabel 11.

\section{Korelasi Determinasi}

Model Summary

\begin{tabular}{ccccc}
\hline Model & R & R Square & $\begin{array}{c}\text { Adjusted R } \\
\text { Square }\end{array}$ & $\begin{array}{c}\text { Std. Error of the } \\
\text { Estimate }\end{array}$ \\
\hline 1 & $.850^{2}$ & .722 & .717 & 6.165 \\
\hline
\end{tabular}

a. Predictors: (Constant), BimbinganPraktikTilawah

b. Dependent Variable: MotivasiMenghafalAlQuran

Sumber:(Data Hasil Output SPSS, April 2018)

Berdasarkan tabel Korelasi Determinasi dapat dilihat besarnya kontribusi variabel X (bimbingan praktik tilawah) terhadap variabel $\mathrm{Y}$ (motivasi menghafal Al-Quran) yang diinterpretasikan pada rumus koefisien determinasi $\mathrm{Kd}=$ $\mathbf{0 , ~ 8 5 0}^{2} \times 100 \%=72,25 \%$. Dengan demikian persentase pengaruh bimbingan praktik tilawah terhadap motivasi menghafal Al-Quran yaitu sebesar $72,25 \%$ dan sisanya sebesar $27,75 \%$ dipengaruhi oleh variabel lain.

\section{PENUTUP}

Berdasarkan hasil analisis data dan pembahasan mengenai pengaruh bimbingan praktik tilawah terhadap motivasi menghafal Al-Quran, dengan 64 responden mahasiswa Angkatan 2014 Jurusan Bimbingan Konseling Islam Fakultas Dakwah dan Komunikasi UIN Sunan Gunung Djati Bandung. Maka dapat ditarik kesimpulan bahwa pengaruh bimbingan praktik tilawah terhadap motivasi menghafal Al-Quran dengan pengambilan sampel sebanyak 64 responden. Dari hasil uji validitas dengan $r_{\text {tabel }}$ yang digunakan 0,2461 maka diperoleh bahwa keseluruhan pernyataan sebanyak 44 item yang terdiri dari 22 item pernyataan bimbingan praktik tilawah dan 22 item pernyataan motivasi menghafal Al-Quran dinyatakan valid. Hasil reliabilitas Cronbach's Alpha variabel 


\section{U. N. Saeful}

$\mathrm{X}$ (bimbingan praktik tilawah) yaitu $0,870 \geq 0,70$ sedangkan nilai variabel $\mathrm{Y}$ (motivasi menghafal Al-Quran) yaitu $0,913 \geq 0,70$ maka semua kontruk pernyataan dapat dikatakan reliabel.

Pengaruh bimbingan praktik tilawah terhadap motivasi menghafal AlQuran memiliki pengaruh yang kuat, dibuktikan dari hasil pengujian data diperoleh nilai signifikan $0,000<0,05$. Hal tersebut menunjukkan bahwa $\operatorname{Pv}<\alpha$ $(0,05)$ sehingga $\mathrm{H}_{0}$ ditolak dan $\mathrm{H}_{1}$ diterima yang berarti terdapat pengaruh yang signifikan bimbingan praktik tilawah terhadap motivasi menghafal Al-Quran. Adapun dari hasil pengolahan data dapat dibuktikan bahwa pengaruh bimbingan praktik tilawah terhadap motivasi menghafal Al-Quran yaitu sebesar $72,25 \%$ dan sisanya sebesar 27,75\% dipengaruhi oleh variabel lain.

Respon mahasiswa Jurusan Bimbingan Konseling Islam Angkatan 2014 Fakultas Dakwah dan Komunikasi UIN Sunan Gunung Djati Bandung terhadap proses pelaksanaan bimbingan praktik tilawah sangat tinggi hal ini disebabkan oleh tata cara atau metode yang dilakukan oleh pembimbing dalam melaksanakan bimbingan.

Mahasiswa Jurusan Bimbingan Konseling Islam Angkatan 2014 Fakultas Dakwah dan Komunikasi UIN Sunan Gunung Djati Bandung memiliki perencanaan dalam aktivitas menghafal Al-Quran, memiliki pencapaian tujuan yang diinginkan, memiliki kesadaran untuk menghafal Al-Quran, menghargai dan menerima pembimbing yang mengajarkan hafalan Al-Quran, serta memiliki rasa ingin tahu yang tinggi dalam proses menghafal Al-Quran.

Berdasarkan kesimpulan di atas, terdapat beberapa saran yang akan penulis sampaikan yaitu kepada mahasiswa untuk lebih meningkatkan rasa tanggungjawab saat diwajibkan untuk mengikuti bimbingan praktik tilawah, tidak menganggapnya sebagai syarat kelulusan saja tetapi lebih daripada itu mahasiswa dapat mengambil hikmahnya setelah menngikuti bimbingan praktik tilawah. Selain itu, perlu adanya rasa optimis bahwa setiap individu mampu untuk menghafal Al-Quran, sehingga mampu memanfaatkan bimbingan praktik tilawah sebagai media dalam membantu menghafal Al-Quran.

Kepada dosen pembimbing agar lebih mengefektifkan proses bimbingan praktik tilawah, khususnya mengenai baca, tulis, dan hafalan Al-Quran kepada setiap mahasiswa yang dibimbingnya.

Kepada lembaga yang bersangkutan lebih memberikan fasilitas yang mendukung untuk pelaksanaan bimbingan praktik tilawah sehingga dapat memberikan motivasi bagi mahasiswa agar lebih rajin dan aktif melaksanakan bimbingan praktik tilawah. 


\section{DAFTAR PUSTAKA}

Abdussalam, A., Fakhruddin, A., Nursahid, Rofik.(2015 ). Program Pembelajaran Tilawah Al-Quran Pada Pondok Pesantren Al-Quran Al-

Falah Cicalengka Bandung (Studi Deskriptif Tentang Program Pembelajaran Tilawah Al-Quran Tahun 2015). Tarbawy : Indonesian Journal Of Islamic Education.

Adawiyah, I. (2016). Bimbingan Tabfidz melalui Media Purzle untuk Meningkatkean Motivasi Menghafal Al-Quran. Skripsi, Jurusan Bimbingan dan Konseling Islam, UIN Sunan Gunung Djati, Bandung.

Aliyudin. (2010). Prinsip-Prinsip Metode Dakwah Menurut Al-Quran dalam Ilmu Dakwah: Academic Journal for Homiletic Studies, 4(15), 2.

Arifin, B. S. (2015). Psikologi Agama (Cetakan ke-2). Bandung: Pustaka Setia.

Badriyah, S. L. (2014). Bimbingan Kelompok dalam Menumbubkan Motivasi Menghafal Al-Quran di Kalangan Santriwati. Skripsi, Jurusan Bimbingan Konseling Islam, UIN Sunan Gunung Djati Bandung.

Bahrudin, B., Kumaidi, K.(2014). Model Asesmen Musabaqah Tilawah AlQuran (Mtq) Cabang Tilawah. Jurnal Penelitian Dan Evaluasi Pendidikan.18(20)

Chaplin, J. P. (2014). Kamus Lengkap Psikologi (Cetakan ke-16). Diterjemahkan oleh: Kartini Kartono. Jakarta: Rajawali Press.

Daulay, M. R. (2014). Studi Pendekatan Al-Quran dalam Jurnal Thariqah Ilmiah Vol: 01 No. 1.

Fakultas Dakwah dan Komunikasi. (2014). Panduan Akademik Fakultas Dakwah dan Komunikasi. Bandung: UIN Sunan Gunung Djati Bandung.

Fakultas Dakwah dan Komunikasi. (2015). Panduan Penyelenggaraan Praktik Tilawah. Bandung: UIN Sunan Gunung Djati Bandung.

Haryanto, E., Cahyana, R. (2015).Pengembangan Aplikasi Mutabaah Tahfidz Alquran Untuk Mengevaluasi Hafalan. Jurnal Algoritma.12(1)

Hijriyanti, T. (2018). Peranan Pembimbing dalam Meningkatkan Hapalan AlQur'an Santri dalam Irsyad: Jurnal Bimbingan, Penyuluban, Konseling, dan Psikoterapi Islam 6(3) 325-244.

Karlina, L. (2016). Pengaruh Bimbingan Agama melalui Program Pengajian Orang Tua terhadap Interaksi Orang Tua dan Anak. Skripsi, Jurusan Bimbingan Konseling Islam, UIN Sunan Gunung Djati Bandung.

Kasyfulbayan, G. G. (2017). Hubungan antara Sikap Mahasiswa terhadap Kebijakan Tabfidz dengan Motivasi Menghafal Al-Quran Juz. 30. Skripsi, Fakultas Psikologi, UIN Sunan Gunung Djati Bandung. Tidak diterbitkan.

Marlina, M. (2018). Teori Behavior dalam Meningkatkan Motivasi Hafalan Surat Pendek Al-Quran dalam Irsyad: Jurnal Bimbingan, Penyuluban, Konseling, dan Psikoterapi Islam 6(4) 413-432. 
Miharja, S. (2013). Bimbingan Karir (Dakwah, Teori dan Praktik). Bandung: Tinta Biru.

Nashir, A., Halib, A. (2016). Sistem Pembinaan Halaqah Terhadap Kecerdasan Emosional Santri Di Markaz Tahfidz Alquran Al-Birr. Jurnal Tarbawi Pendidikan Agama Islam.1(2)

Noor, H. F. (2015). Ekonomi Media. Jakarta: Rajagrafindo Persada.

Pusat Bahasa. (2014). Kamus Besar Bahasa Indonesia; Edisi Kedelapan. (Cetakan ke18). Jakarta: PT Gramedia Pustaka Utama.

Riyadi, A. (2013). Bimbingan Konseling Perkawinan; Dakwah dalam Membentuk Keluarga Sakinah. Yogyakarta: Penerbit Ombak.

Sugiyono. (2013). Metode Penelitian Kuantitatif, Kualitatif dan R\&D (Cetakan ke 19). Bandung: CV. Alfabeta.

Untomo, dkk. (2015). Fungsi Rumah Tilawah Ikhwah Rasul Dalam Penanaman Nilai-Nilai Keislaman (Studi Pada Mahasiswa Universitas Negeri Semarang). Solidarity: Journal Of Education, Society And Culture.4(2)

Willis, S. S. (2014). Konseling Individual; Teori dan Praktek. Bandung: Alfabeta.

Yusuf L. N., S. dan A. Juntika N. (2014). Landasan Bimbingan dan Konseling (Cetakan ke-8). Bandung: PT Remaja Rosdakarya. 